\title{
English Language Teachers' Assessment Literacy: The Turkish Context
}

\begin{abstract}
Assessment is considered to be a critical component in the process of teaching and learning as it enables teachers to evaluate student learning and utilize the information to improve learning and instruction. One of the most important aspects in the quality assurance of language testing and assessment (LTA) is the assessment literacy of teachers. Foreign language teachers particularly have to deal with their own classroom-based assessment as well as standardized language tests. The present study aims to explore the assessment literacy of English teachers working at the preparatory school in foundation (non-profit, private) universities in Turkey. Data collected by means of an online LTA questionnaire and focus group interviews revealed crucial findings about the areas the Turkish EFL teachers received pre- or in-service training in the LTA domain, their perceived needs for an in-service training in this field as well as their attitudes towards the testing/ assessment practices in language preparatory programs.
\end{abstract}

Keywords: Language Assessment, Assessment Literacy, Teachers' Perceived Needs, Attitudes, Preparatory Program, EFL.

* Asst. Prof. Dr. , Bahçeşehir Üniversitesi.

** Prof. Dr., Bahçeşehir Üniversitesi.

Enisa Mede* - Derin Atay** $\ddot{0} z$

İngilizce Öğretmenlerinin Dil Değerlendirmesi Okuryazarlığı: Türkiye Bağlamı

Değerlendirme, öğretme ve öğrenme sürecini iyileştirmek için öğretmenlerinin bilgiyi kullanmasını sağlayan kritik bir bileşendir. Yabancı dil değerlendirmenin kalite güvencesinde en önemli hususlardan biri, öğretmenlerin değerlendirme okuryazarlı̆̆ıdır. Yabancı dil öğretmenleri, özellikle sinıf temelli değerlendirmelerinin yan sıra standartlaştırılmış dil testleriyle uğraşmak zorundadırlar. Bu çalışma, Türkiye'de (kar amacı gütmeyen, özel) üniversitelerdeki hazırlık programlarında çalışan İngilizce öğretmenlerinin değerlendirme okuryazarlığını araştırmayı amaçlamıştır. Çevrimiçi bir anket ve odak grup görüşmeleriyoluyla veriler toplanmıştır. Çalışmanın sonucu Türkiye'deki İngilizce öğretmenlerinin değerlendirme alanında hizmet içi eğitim aldıkları alanlar hakkında önemli bulguları, bu alanda hizmet içi eğitim için algılanan ihtiyaçlarını ve dil hazırlik programlarındaki test/değerlendirme uygulamalarına yönelik tutumlarmı ortaya koymuştur.

Anahtar kelimeler: Yabancı Dilde Değerlendirme, Değerlendirme Okuryazarliğı, Öğretmenlerin Algılanan İhtiyaçları, Tutumlar, Hazırlık Programı, Yabancı Dil Olarak İngilizce. 


\section{Introduction}

Assessment is considered to be a critical component in the process of teaching and learning as it enables teachers to evaluate student learning and utilize the information to increase learning through changing and improving their instructional practices (Harris, Irving, \& Peterson, 2008). Teachers gather information about the students' progress, and try to understand to what extent instructional methods used achieve the intended teaching and learning outcomes (Gronlund, 1998). According to Huba and Freed (2000) assessment is a process of gathering and discussing information from various sources to develop a deep understanding of what students know, understand, and can do with their knowledge as a result of educational experiences. Thus, assessment can be described as any technique, tool or strategy that teachers use to elicit evidence of students' progress toward the stated goals (Chen, 2003).

Traditional classroom assessment involves various activities, such as constructing paperpencil tests and performance measures, grading, interpreting, and communicating assessment results, and using them in making educational decisions. In the last years, educational reforms have heralded new classroom assessment approaches that go beyond traditional paper and pencil techniques to include alternative performance assessment methods. Such alternative assessments focus more on motivating students to take more responsibility for their own learning, and intend to make assessment an integral part of the learning experience and to stimulate student abilities to create and apply a wide range of knowledge rather than simply engaging in acts of memorization (Stiggins, 1997; Zhang, \& Burry-Stock, 2003).

Teachers in a number of studies are observed to spend up to $50 \%$ of their time on assessment related activities (Plake, 1993); thus, they need to develop assessment literacy to spend this time effectively and practice the relevant knowledge and skill regularly in their classrooms. Assessment literacy has been defined as an understanding of the principles of sound assessment (Popham, 2004) and it is the teacher's capacity to examine student performance evidence and discern quality work through the analysis of achievement scores (Fullan, 2001). Teachers need to have knowledge on different assessment methods, their purposes, functions, intended and unintended consequences and how to mesh traditional and creative classroom assessments. Whatever tests and performance measures they use, teachers should be aware of the strengths and weaknesses of each and choose appropriate formats to assess different achievement targets which should match with course objectives and instruction. They should be able to share the grading criteria with the students and interpret test scores appropriately and use assessment results to make decisions about students' educational issues. 
Teachers who have a solid background in assessment are "not intimidated by the sometimes mysterious and always daunting technical world of assessment" (Stiggins, 2002, 240), and are able to integrate assessment with instruction (McMillan, \& Nash, 2000). Good classroom assessment enables teachers to draw accurate inferences about individual student achievement and communicate that information to students and parents (Brookhart, 1999).

With increasing interest in testing and assessment, expectations regarding teachers' classroom practices have undergone a paradigm shift (Hargreaves, Earl, \& Schmidt, 2002). Teachers are more and more expected to incorporate various assessment practices as overreliance on one assessment method makes it virtually impossible for teachers to adapt teaching and learning to meet individual student needs (Stiggins, 2002). Earl (2003) similarly advocates for synergy among assessment for learning, i.e., formative assessment conducted to monitor students' learning process, assessment of learning, i.e., summative assessment, and assessment as learning conducted so as to enable individual learners to assess their own learning (Balagtas et al., 2010). In all these visions the common point is that teachers must recognize different purposes of assessment and use them accordingly (Green \& Mantz, 2002).

However, despite the increasing need for teacher assessment literacy, research indicates limited pre-service assessment education and a lack of research on the pedagogies that support teachers' assessment practices (Galluzzo, 2005; Mertler, 2003). Collecting data from 69 teacher candidates in all four years of their concurrent programs within a large Canadian urban setting, Volante and Fazio (2007) found that most candidates favored only summative assessment and lacked other forms of assessment knowledge, and their levels of self-efficacy regarding assessment remained relatively low across each of the four years of program. To improve their assessment literacy, teacher candidates overwhelmingly endorsed the development of specific courses focusing on classroom assessment. This finding extends to in-service teachers in many parts of the world who also tend to utilize unsound assessment practices (Çalışkan, \& Kaşıç̧ı, 2010; Yamtim, \&Wongwanich, 2014). Many teachers are observed to be largely unprepared to effectively integrate assessment into their practice, with beginning teachers particularly lacking in confidence in this area (Mertler, 2004). In-service teachers in a number of contexts report feeling ill-prepared to assess student learning and claim that their lack of preparation is largely due to inadequate pre-service training in educational measurement (Karaman, \& Şahin, 2014). Finally, a study conducted by Mertler (1999) further revealed that teachers tended to develop assessment skills on the jobs as opposed to structured environments such as courses or workshops. 


\section{Language Testing and Assessment}

Language testing has witnessed an unprecedented expansion during the first part of the $21^{\text {st }}$ century; there is an increased emphasis on authentic, performance-based assessment to reflect what students need to do with the language in real-life settings (Wiggins, 1994) as well as on shared, common standards with which to assess students. Within this framework, assessment responsibilities of language teachers increase accordingly. Depending on the context, language teachers are asked to organize and administer classroom language assessment activities themselves and to deal with local as well as external testing procedures and policies. However, despite the importance given on a global scale, language teachers' testing and assessment literacy (LTA) has been highly questioned. Alderson (2005), for example, claims that many language tests prepared by the teachers are of low quality. Similarly, Gardner and Rea-Dickins (2001) found that many English language teachers had a limited set of language testing terms. Hasselgreen, Carlsen, and Helness (2004) conducted a survey designed to uncover the assessment training needs of teachers in Europe; results revealed that language teachers needed training in areas such as portfolio assessment, preparing classroom tests, peer and self-assessment, item writing, interviewing and rating among many other areas.

The present study aims to contribute to the field of LTA by adding and expanding the data collected by Vogt and Tsagari (2014). The aim of their study was to explore foreign language teachers' foreign language teachers' language teachers' testing and assessment literacy across Europe (Former Yugoslavian Republic of Macedonia (FYROM); Germany, Greece, Italy, Poland) as well as Cyprus and Turkey by focusing on the training needs of foreign language teachers, their current background in the different areas of LTA, and the extent to which they had received training in testing and assessment domains during their pre- and in-service education. The data obtained from the questionnaires and interviews revealed that despite the small difference across countries, only certain domains of teachers' LTA literacy was developed. Although the participating teachers expressed that they had been learning about LTA in their institutions, they still needed training in this field with varying priorities.

As shown in the previous literature studies, no study was conducted particularly in the Turkish context on this issue. Although the study conducted by Vogt and Tsagari (2014) focused on teachers' LTA literacy across different countries including Turkey, the findings regarding only three countries (Germany, Greece and Cyprus) were reported and discussed in detail as the number of the participants from these countries was higher.

In light of these observations, to address the gaps in previous research, the present study aims to gather in-depth information about the LTA literacy of Turkish ELT teachers at 
tertiary level and in line with this purpose, the following research questions were addressed in this study:

a. In what areas do the Turkish EFL teachers receive pre- or in-service training in the LTA domains?

b. What are the Turkish EFL teachers' perceived needs for an in-service training in the LTA domains?

c. What are the attitudes of the Turkish EFL teachers about the LTA practices at the language preparatory programs?

\section{Method}

\subsection{Research Design}

The present study employs mixed method as a research design (Onwuegbuzie \& Johnson, 2004) that combines quantitative and qualitative research techniques into a single study. The quantitative data was collected by means of an online LTA questionnaire adapted from Vogt and Tsagari (2014) to find out the training practices and needs of Turkish EFL teachers and qualitative came from focus group interviews carried out with three group of volunteer participating teachers, each group comprising 10-12 teachers. Overall, the rationale behind choosing a mixed-method design in this study was to provide an in-depth analysis on: a) the level of competency toward received training in LTA, b) the need for training in LTA domains and c) the testing practices of Turkish EFL teachers.

\subsection{Setting and Participants}

This study was conducted with EFL teachers working at the language preparatory programs offered by state $(n=4)$ and private $(n=7)$ universities in Turkey. The primary aim of these programs is to enhance students' four language skills, grammar and vocabulary before they start their undergraduate studies at different disciplines. The preparatory programs generally last for one academic year (from September to July), providing students with A1, A2, B1, B2 and C1 proficiency levels of English defined by the Common European Framework (CEFR/CEF). Each level lasts approximately 8 weeks (referred to as a teaching module) and the students are further intermittently assessed via variety of exams such as quizzes and midterms as well as tasks throughout each module. At the end of every module, the students take an End of Module Exam (EOM) and their combined average in the exams, tasks and the EOM shows their language proficiency score (minimum 65) to finish the preparatory program and start their undergraduate studies at various disciplines. 
The participants of this study were 350 EFL teachers ( 153 males and 197 females) with age ranging from 25 to 35 years old. All participants had their majors in English Language Teaching (ELT) with at least 5 years of teaching experience.

\subsection{Data Collection Instruments}

The online questionnaire used in the present study was adapted from Vogt and Tsagari's (2014) study which aimed to find out the classroom-oriented LTA practices and needs of FL teachers from seven European countries was used as a starting point. One particular item related to the 'awarding final certificates' was excluded from the questionnaire as this it was not applicable to the LTA practices in Turkish EFL context. Instead, a new item on 'using evaluation rubrics' was added as it a commonly used testing and assessment strategy in language preparatory programs.

The questionnaire consisted of two major parts. The first part (Part 1) had three sub-parts: a) teachers' classroom-focused LTA practices, b) purposes of testing and c) content and concepts of LTA. In all these three sub-parts, the respondents were asked in what assessment and training domains they received training and in which of those domains they need further training. The questionnaire was based on a 3-point Likert-type scale ranging from "not at all" (1) to "more advanced"(3). As for the second part of the questionnaire (Part 2), 3 open-ended questions were included with at attempt to get insight about the attitudes of the participating teachers about the LTA practices at language preparatory programs.

Before the questionnaire was administered to the participants, it was piloted with 176 English teachers. The reliability estimates ranged from .73 to .87 indicating a high level of internal consistency (Gliem, \& Gliem, 2003). After piloting the questionnaire, it was sent to 557 Turkish EFL teachers online via Survey Monkey. 350 of the participating teachers responded back to the questionnaire.

Furthermore, to complement the quantitative data, focus group interviews were carried out with 34 EFL teachers enrolled in language preparatory programs to gather in-depth information about the perceptions and needs of the participants about LTA domains as well as identify their LTA classroom practices. The purpose of using this particular type of interview was to generate data based on the synergy of the group interaction (Green et al., 2003). During the interview, the participating teachers were asked whether they had received any training on testing and to what extent they could apply what they had learned in their LTA practices. They were also asked about the types of testing and assessment used in their institution along with their roles in the LTA domains and their attitudes of the participants about the LTA practices. 


\subsection{Data Analysis}

In this study, data collected from the online questionnaire were entered into and analyzed statistically via SPSS (version 20.0). Frequencies and percentages were estimated to analyze and report the gathered data. To complement the quantitative findings, focusgroup interviews were analyzed through pattern coding (Bogdan, \& Biklen, 1998). The process began with the open coding of the data followed by inducing categories from these codes. The categories and themes were subject to the checking of inter-raters. To identify the degree of inter-rater reliability, two experts in the field of English Language Teaching (ELT) identified themes from the codes. The inter-rater reliability for the raters was found to be .86 which indicated close agreement on the general themes apart from the different verbalizations of similar concepts.

\section{Findings}

\subsection{The Perceptions of the Turkish EFL Teachers about the Received Inservice Training in the LTA Domains}

In the following section, the findings of the first research question regarding the perceptions of the Turkish EFL teachers about the received in-service training in the LTA domains as well as the sufficiency of this training are reported using frequencies $(f)$ and percentages (\%). Specifically, the questionnaire results were reported under three LTA domains: a) classroom-focused LTA, b) purposes of testing and c) content and concepts of LTA.

\subsubsection{Classroom-focused LTA of Turkish EFL Teachers}

The following tale presents the overall results of classroom-focused LTA domain reporting the perceptions of the Turkish EFL teachers about their received training:

Table 1: Turkish EFL Teachers' Received Training on Classroom-Focused LTA

\begin{tabular}{|l|c|c|}
\hline Training Received & $f$ & $\%$ \\
\hline Preparing classroom tests Not at all from textbook packages & 80 & 22 \\
A little & 210 & 60 \\
More advanced & 60 & 18 \\
\hline Preparing ready-made tests Not at all & 130 & 38 \\
A little & 170 & 48 \\
More advanced & 50 & 14 \\
\hline Giving feedback Not at all & 160 & 45 \\
A little & 30 & 37 \\
More advanced & 60 & 18 \\
\hline
\end{tabular}




\begin{tabular}{|l|c|c|}
\hline Giving feedback Not at all & 170 & 48 \\
A little & 150 & 43 \\
More advanced & 30 & 9 \\
\hline Giving feedback Not at all & 100 & 29 \\
A little & 210 & 60 \\
More advanced & 40 & 11 \\
\hline Using ELP or Portfolio Not at all & 160 & 46 \\
A little & 160 & 46 \\
More advanced & 30 & 8 \\
\hline
\end{tabular}

As shown in the table above, $22 \%$ of the Turkish EFL teachers stated that they did not receive any training in terms of "preparing classroom test" while $60 \%$ state that they had little training on this particular testing component. Finally, $18 \%$ of the respondents reported that they had more advanced training in this subdomain related to preparing classroom tests. Similarly, for "ready-made tests" the participating teachers said that they had no $(38 \%)$ or little (48\%) training in this area. Lastly, only $14 \%$ of the teachers had more advanced level of training.

On the other hand, "feedback on assessment" and "informal feedback" were the two areas that the respondents did not receive any $(45 \%$ and $48 \%)$ or had very little training (37\% and $43 \%)$. Only a small number of teachers (18\% and $9 \%$, respectively) expressed that they had more advanced training in these two fields.

Considering "self or peer assessment", $60 \%$ of the participants reported to have little or no training (29\%). Only $11 \%$ of the respondents perceived themselves as were more advanced in this area.

Finally, most of the participants had some training in using portfolios (60\%), whereas $22 \%$ received no training at all. Finally, only $18 \%$ of the participating teachers were more advanced in the use of portfolios in their LTA practices.

Based on these findings, it is obvious that the Turkish EFL teachers were lacking training in classroom focused LTA. Specifically, they were in a need for more advanced training in classroom focused LTA to be integrated in the inservice training of the existing program.

\subsubsection{Purposes of Testing}

Table 2 presents the extent Turkish EFL teachers had training in LTA domains according to the different purposes. 
Table 2: Turkish EFL Teachers Received Training on Purposes of Testing

\begin{tabular}{|l|c|c|}
\hline Training Received & $f$ & $\%$ \\
\hline Testing receptive skills Not at all & 130 & 36 \\
A little & 170 & 47 \\
More advanced & 50 & 14 \\
\hline Testing productive skills Not at all & 100 & 29 \\
A little & 150 & 42 \\
More advanced & 100 & 29 \\
\hline Testing microlinguistic aspect Not at all & 90 & 28 \\
(grammar and vocabulary) & 80 & 22 \\
A little & 180 & 50 \\
More advanced & & \\
\hline Testing integrated language Not at all & 100 & 27 \\
skills & 150 & 45 \\
A little & 100 & 27 \\
More advanced & 90 & 28 \\
\hline Testing aspects of culture Not at all & 130 & 36 \\
A little & 130 & 36 \\
\hline More advanced & 120 & 35 \\
\hline Reliability Not at all & 120 & 35 \\
A little & 110 & 30 \\
More advanced & 80 & 22 \\
\hline Validity Not at all & 130 & 36 \\
A little & 140 & 42 \\
More advanced & 110 & 31 \\
\hline Using statistics Not at all & 110 & 31 \\
A little & 140 & 38 \\
\hline More advanced & & \\
\hline
\end{tabular}

Considering the domain on "purposes of testing", the participating Turkish EFL teachers shared highly positive perceptions. For example, they reported that they had received little or more advanced training in "giving grades" ( $46 \%$ and $46 \%$, respectively), "finding out what to be taught and learned" (55\% and 42\%), "placing students" (51\% and 43\%) and "using evaluation rubrics (49\% and 40\%). Only a few of the respondents expressed that they had no training $(8 \%, 3 \%, 6 \%$ and $11 \%$, respectively) in these four areas which shows that the Turkish EFL teachers were competent in the purposes of testing. These findings revealed that the Turkish EFL teacher were more competent in the domain on the purposes of testing. 


\subsubsection{Content and concepts of LTA}

The final section of the questionnaire aimed to provide more specific data about the content of training teachers received. Table 3 below reports each finding in detail:

\section{Table 3: Turkish EFL Teachers' Received Training on Content and Concepts of LTA}

\begin{tabular}{|l|c|c|}
\hline Training Received & $f$ & $\%$ \\
\hline Testing receptive skills Not at all & 130 & 36 \\
A little & 170 & 47 \\
More advanced & 50 & 14 \\
\hline Testing productive skills Not at all & 100 & 29 \\
A little & 150 & 42 \\
More advanced & 100 & 29 \\
\hline Testing microlinguistic aspect Not at all & 90 & 28 \\
(grammar and vocabulary) & 80 & 22 \\
A little & 180 & 50 \\
More advanced & 100 & 27 \\
\hline Testing integrated language Not at all & 150 & 45 \\
skills & 100 & 27 \\
A little & & 28 \\
More advanced & 90 & 36 \\
\hline Testing aspects of culture Not at all & 130 & 36 \\
A little & 130 & 35 \\
More advanced & 120 & 35 \\
\hline Reliability Not at all & 120 & 30 \\
\hline A little & 110 & 22 \\
More advanced & 80 & 36 \\
\hline Validity Not at all & 130 & 42 \\
A little & 140 & 31 \\
More advanced & 110 & 31 \\
\hline Using statistics Not at all & 110 & 38 \\
\hline A little & 140 & \\
More advanced & & \\
\hline
\end{tabular}

According to the findings displayed in the table above, the majority of Turkish EFL teachers received little training in "receptive, productive and integrated language skills" ( $47 \%, 42 \%$ and $45 \%$, respectively). However, they picture changed a little bit in terms of their training on the "microlinguistic aspect of language". In other words, they perceived to be more competent in testing grammar and vocabulary (50\%). Besides, "aspects of culture" another important area that the participants showed different level of competency ( $28 \%$ 
no training, 36 little training and 36\% more advance training, respectively). Lastly, they respondents showed variety in relation to receiving training about validity, reliability and using statistics in assessment. While some had no (35\%, $22 \%$ and $31 \%)$ or little $(35 \%, 36 \%$ and $31 \%)$ training in these areas, others reported to be more competent $(30 \%, 42 \%$ and $48 \%$, respectively).

To briefly summarize, the participating EFL teachers showed some variety in terms of their competence on the content and concepts of LTA. Although some of them were previously trained, others still needed support in this particular LTA domain.

\subsection{The Perceptions of the Turkish EFL Teachers about their Needs on LTA Training}

In an attempt to answer the second research question which aimed to identify the perceived needs of participating teachers about LTA training, the questionnaire findings are thoroughly presented under the same assessment subdomains of the previous section.

\subsubsection{Classroom focused LTA}

In the following table, the findings about the needs of the participating teaches on classroom-focused LTA are displayed:

Table 4: Perceptions of Turkish EFL Teachers about Training Needed in Classroom-

\section{Focused Testing}

\begin{tabular}{|l|c|c|}
\hline Training Needed & $f$ & $\%$ \\
\hline Preparing classroom tests None & 0 & 0 \\
Basic training & 170 & 48 \\
Advanced & 180 & 52 \\
\hline Ready-made tests None & 0 & 0 \\
Basic training & 110 & 32 \\
Advanced & 240 & 68 \\
\hline Feedback on assessment None & 0 & 0 \\
Basic training & 60 & 18 \\
Advanced & 290 & 82 \\
\hline Informal assessment None & 0 & 0 \\
Basic & 100 & 29 \\
Advanced & 250 & 71 \\
\hline Self or peer assessment None & 0 & 0 \\
Basic & 170 & 48 \\
Advanced & 180 & 52 \\
\hline ELP or Portfolio None & 0 & 0 \\
Basic & 140 & 40 \\
Advanced & 210 & 60 \\
\hline
\end{tabular}


According to the results displayed in the Table 4 above, all of the respondents were in a high need for training in the classroom-focused LTA domain. To exemplify, they all asked for training (either basic or advanced) while "preparing classroom" (48\% and 52\%) and "ready-made tests" (32\% and 68\%).

Moreover, they were in a need for advanced training in "providing feedback on assessment" (82\%). Similarly, they asked for intensive training in different types of assessment namely, "informal assessment" (71\%), "self or peer assessment" (52\%) and "ELP or Portfolio assessment" (60\%).

\subsubsection{Purposes of LTA}

Considering the needs of the Turkish EFL teachers about the need for training in the purposes of LTA, findings parallel to the classroom-focused LTA were obtained (see Table 5).

Table 5: Perceptions of Turkish EFL Teachers about Training Needed in Purposes of Testing

\begin{tabular}{|l|c|c|}
\hline Training Needed & $f$ & $\%$ \\
\hline Giving grades None & 40 & 11 \\
Basic & 170 & 49 \\
Advanced & 140 & 40 \\
\hline Finding out what needs to be None & 10 & 3 \\
taught/learned & 100 & 27 \\
Basic & 240 & 70 \\
Advanced & 10 & 3 \\
\hline Placing students None & 150 & 42 \\
Basic & 190 & 55 \\
Advanced & 10 & 3 \\
\hline Using evaluation rubrics None & 160 & 35 \\
Basic & 180 & 62 \\
Advanced & & \\
\hline
\end{tabular}

As shown in the table above, all of the participants needed training in the domain on purposes of testing. Specifically, the most advanced training was needed while "finding out what needs to be taught/learned" (70\%) and "using evaluation rubrics" (62\%). Besides, the respondents needed training (either basic or advanced) in relation to "giving grades" (49\% and $40 \%$ ) as well as placing students ( $42 \%$ and $55 \%)$. 


\subsubsection{Content and Concepts of Testing}

The final part in the questionnaire was related to the needs of the respondents about training in content and concepts of testing as illustrated in the following table:

Table 6: Perceptions of Turkish EFL Teachers about Training Needed in Content and Concepts of Testing

\begin{tabular}{|l|c|c|}
\hline Training Needed & $f$ & $\%$ \\
\hline Testing receptive skills None & 0 & 0 \\
Basic & 100 & 29 \\
Advanced & 250 & 71 \\
\hline Testing productive skills None & 10 & 4 \\
Basic & 100 & 28 \\
Advanced & 240 & 68 \\
\hline Testing microlingusitic aspect None & 240 & 68 \\
Basic & 110 & 32 \\
Advanced & 0 & 0 \\
\hline Testing integrated None language skills & 10 & 2 \\
Basic & 120 & 35 \\
Advanced & 220 & 63 \\
\hline Aspects of culture None & 30 & 8 \\
Basic & 160 & 46 \\
Advanced & 160 & 46 \\
\hline Reliability None & 10 & 3 \\
Basic & 180 & 52 \\
Advanced & 160 & 45 \\
\hline Validity None & 20 & 6 \\
Basic & 180 & 52 \\
Advanced & 150 & 42 \\
\hline Using statistics None & 10 & 3 \\
Basic & 150 & 42 \\
Advanced & 190 & 55 \\
\hline
\end{tabular}

Based on the findings displayed in Table 6 above, the Turkish EFL teachers asked for advanced training in assessing "receptive, productive skills and integrated language skills" (71\%,68\% and 63\%, respectively). On the contrary, the respondents perceived themselves as being competent in testing microlingusitic aspects of a language grammar and vocabulary, 69\%). Thus, they did not ask for any training in this area. In addition, assessing "aspects of culture" was considered to be an important component by the participating teachers. They asked for a basic or advanced training in this area (46\%). Finally, the participants 
needed to be trained with respect to establishing "reliability" and "validity" as well as "using statistics". In other words, they needed training in these three fields (52\%, 52\% and 42\%, basic training) and (45\%, 42\% and 55\%, more advanced training).

The analyses of the three open-ended questions at the end of the online questionnaire aimed at getting more information in relation to the testing and assessment practices and training of the participants revealed that the EFL instructors at tertiary level mainly assessed students' reading, writing and listening skills by means of tests and quizzes (94\%), prepared by the testing offices; speaking skill was only tested once or twice year as part of the proficiency exam in only two of the universities.

Regarding the second question, $62 \%$ of the teachers indicated that they had a "testing and evaluation" course in their pre-service education program which they found highly "insufficient". Besides, 56\% of the teachers in this group indicated that the CELTA and DELTA courses they attended helped them to update their assessment literacy. Only $48 \%$ of them had training on the premises; though these were short, one-shot trainings, they seemed to help participating teachers in terms of awareness-raising regarding the importance of assessment as indicated by the following quote of a teacher:

[... Assessment is an ongoing process; I try to involve my learners in this process through self- and peer assessment as much as I could learn in the training I attended; yet I feel I still need some support with the process (EFL teacher, interview data, $11^{\text {th }}$ April, 2016).

Besides, there were a few teachers who claimed that the trainings were "too exam oriented" and the aim should be to improve students' communicative skills rather than to prepare students for tests.

The majority of the teachers $(78 \%)$ equated assessment training with sessions on the use of rubrics for writing and speaking assessment; they claimed that these sessions given by the testing office of the university taught them what "to look for" when evaluating a student paragraph, essay or oral presentation.

Overall, the participants said they "had to" use the tests and quizzes given by the testing office and "had to" assess these according to the suggested rubrics. Other than these, they did not prepare any assessment in their classes.

The focus group interviews conducted with five groups of teachers from both state and private universities aimed to find out participating teachers' attitudes towards the LTA practices in their institutions; analyses revealed two major themes: necessity of standardization vs. lack of autonomy. 
As afore mentioned, all quizzes and tests were prepared by the testing office; this practice was endorsed by the teachers because they felt the need for standardization as can be seen in the following quotes:

[...] If all teachers were asked to prepare their own tests, there would a lot of difference and this would lead to a subjective assessment and chaos among students. Students should be given the same tests; if not, they would rebel (EFL teacher, interview data, $11^{\text {th }}$ April, 2016).

However, a number of teachers felt that with this system they had no autonomy at all. In one private university, teachers said they could assign a performance task worth of $5 \%$ of the final grade. They had the 'freedom' to choose the topic on their own and share the guidelines with their students. Many complained that they could not integrate the communicative tasks they wanted.

[... Students are not willing to do presentations when they hear that they won't get a grade. Sometimes I want to do something new, a communicative task or a discussion of a cultural issue, but get reaction right away (EFL teacher, interview data, $11^{\text {th }}$ April, 2016).

Based on these findings, EFL teachers' comments revealed their dilemma related to assessment; on one hand, they supported standard assessment practices and on the other, they wanted more autonomy in their assessment practices and not feel confined with the tests and focus more on the "use" of language. However, the majority of them did not feel "confident" to prepare a test; if given the opportunity, they said they would "mostly prepare quizzes to make students prepared all time" yet "more serious issues like validity or reliability of the assessment" would be beyond their "capacity" and "knowledge".

\section{Discussion}

The aim of the present study was to explore the LTA literacy of Turkish ELT teachers working at university prep schools, specifically the extent of their LTA training, their perceived training needs related to different LTA domains and lastly, and identify their attitudes about the LTA practices at their institutions.

According to the findings of the online questionnaire and focus group interviews, the Turkish EFL teachers' LTA was quite limited. Considering the three domains of LTA, the participating teachers needed training mostly in classroom focused LTA as well as content 
and concepts related to assessment. To exemplify, they lacked training in the areas such as preparing classroom tests and providing feedback (informal, self or peer feedback) which shows that they needed support in test design and testing procedures.

Furthermore, similar findings were gathered from the content and concepts of LTA. The teachers were not competent with testing productive and receptive skills along with integrated skills which shows their need for further training in these fields.

The only area they were comfortable with was testing microlingusitic aspect of a language; in other words, grammar and vocabulary. A possible reason behind this finding might be the dominance of grammar instruction in most EFL programs in Turkey. As the teachers are used to teach grammar and introduce new vocabulary items in the classroom, they feel more flexible with testing the microlingusitic component of a language. Besides, the participating teachers were not familiar with the testing terms such as, reliability, validity and using statistics either which supported their need for training in these subdomains.

On the other hand, the Turkish EFL teachers perceived to be more competent in the purposes of testing. They had received training in giving grades, placing students, finding out what they need and using evaluation rubrics. As in most language preparatory programs, teachers are mostly involved in such practices, they felt more competent in the domain on the purposes of testing.

Furthermore, the findings of the qualitative data were quite similar. The Turkish EFL teachers expressed the need for training in productive skills particularly speaking. Besides, the teachers stated that the training they had received were not much sufficient as they were mostly one-shot trainings and too exam oriented. Finally, necessity of standardization and lack of autonomy were the two crucial terms that the participating teachers asked to me more emphasized in the LTA training. The asked for more standardization of the exams as well as integration of communicative tasks in their testing practices.

\section{Conclusion}

The findings of the present study revealed that there is a need for training in Turkish EFL context with respect to LTA domains. Despite some of the differences between the LTA training received and needed, it is obvious that in-service training should focus on implementing various forms of assessment in language preparatory programs. Collaborative training programs, therefore, should emphasize on the needs and priorities EFL instructors' classroom practices which would enhance assessment literacy and competency level in language preparatory programs across Turkey. 
Dil Dergisi $\bullet$ Says: $168 / 1 \cdot 0$ cak-Haziran 2017

\section{References}

Alderson, J. C. (2005). Diagnosing foreign language proficiency: The interface between learning and assessment. London: Continuum.

Balagtas, M. U., Dacanay, A. G., Dizon, M. A. \& Duque, R. E. (2010). Literacy level on educational assessment of students in a premiere teacher education institution: Basis for a capability building program. The Assessment Handbook, 4(1), 1-19. Retrieved from http://pemea.club. officelive.com/TheAssessmentHandbook.aspx

Bogdan, R. C., \& Biklen, S. K. (1998). Qualitative research in education: An introduction to theory and methods (3rd ed.). Needham Heights, MA: Allyn \& Bacon.

Brookhart, S. M. (1999). The Art and Science of Classroom Assessment: The Missing Part of Pedagogy. ASHE-ERIC Higher Education Report, 27 (1). Washington, D.C.: George Washington University Graduate School of Education and Human Development.

Chen, H. (2003). A study of primary school English teachers' beliefs and practices in multiple assessments: A case study in Taipei City. Unpublished master thesis. Taipei: National Taipei Teachers College.

Çalışkan, H., \& Kaşıkçı, Y. (2010). The application of traditional and alternative assesment and evaluation tools by teachers in social studies. Procedia-Social and Behavioral Sciences, 2, 4152 4156.

Earl, L. (2003). Assessment as learning. Thousand Oaks, CA: Corwin.

Fullan, M. (2001). Leading in a Culture of Change. San Francisco: Jossey-Bass.

Galluzzo, G. R. (2005). Performance assessment and renewing teacher education. Clearing House, $78(4), 142-45$.

Gardner, S., \& Rea-Dickins, P. (2001) Conglomeration or Chameleon? Teachers' Representations of Language in the Assessment of Learners with English as an Additional Language. Language Awareness, 10(2-3): 161-77.

Gliem, J., \& Gliem, R. (2003). Calculating, interpreting, and reporting Cronbach's Alpha Reliability

Coefficient for Likert-type scales. Midwest Research-to-Practice Conference in Adult, Continuing, and Community Education.

Green, J. M, Draper, A.K, \& Dowler, E.A. (2003) Short cuts to safety: Risk and 'rules of thumb' in accounts of food choice. Health, Risk and Society 5: 33-52.

Green, S. K., \& Mantz, M. (2002). Classroom assessment practices: Examining impact on student learning. Paper presented at the Annual Meeting of the American Educational Research Association, New Orleans, LA.

Gronlund, N. E. (1998). Assessment of Student Achievement (6th ed.). Boston: Allyn \& Bacon.

Hargreaves, A., Earl, L., \& Schmidt, M. (2002). Perspectives on alternative assessment reform. American Educational Research Journal, 39(1), 69-95.

Harris, L., Irving, S. E., \& Peterson, E. (2008). Secondary Teachers' Conceptions of the Purpose of Assessment and Feedback. Paper presented at the Australian Association for Research in Education Conference, Brisbane.

Hasselgreen, A., Carlsen, C., \& Helness, H. (2004). European Survey of Language Testing and Assessment Needs. Report: part one: general findings. Available at: www.ealta.eu.org/resources. htm (March 2017). 
Huba, M. E., \& Freed, J. E. (2000). Learner-Centered Assessment on College Campuses: Shifting the Focus from Teaching to Learning (1st ed.). Pearson.

Karaman, P., \& Şahin, Ç. (2014). Öğretmen adaylarının ölçme değerlendirme okuryazarlıklarının belirlenmesi. Ahi Evran Üniversitesi Kirşehir Eğitim Fakültesi Dergisi, 15(2). 175-189.

McMillan, J.H., \& Nash, S. (2000). Teachers'classroom assessment and grading decision

making. Paper presented at the Annual Meeting of the National Council of Measurement in Education, NewOrleans.

Mertler, C. A. (1999) Assessing student performance: A descriptive study of the classroom assessment practices of Ohio teachers. Education, 120, 285-96.

Mertler, C. A. (2003). Preservice versus inservice teachers' assessment literacy: Does classroom experience make a difference? Paper presented at the Annual Meeting of the MidWestern Educational Research Association, Columbus, $\mathrm{OH}$.

Mertler, C.A. (2004). Secondary teachers' assessment literacy: Does classroom experience make a difference? American Secondary Education, 33 (1).

Onwuegbuzie, A. J., \& Johnson, R. B. (2004, April). Validity issues in mixed methods research. Paper presented at the annual meeting of the American Educational Research Association, San Diego, CA.

Plake, B. S. (1993). Teacher assessment literacy: Teachers' competencies in the educational assessment of students. Mid-Western Educational Researcher, 6(1), 21-27.

Popham, W. J. (2004). All about accountability / Why assessment illiteracy is professional suicide. Educational Leadership, 62(1), 82-83.

Stiggins, R. J. (1997). Student-centered classroom assessment. Upper Saddle River, NJ: Merrill Prentice Hall.

Stiggins, R. J. (2002) Assessment crisis! The absence of assessment FOR learning. Phi Delta Kappan. 83(10), 758-765.

Stiggins, R. J., Arter, J. A., Chappuis, J., \& Chappuis, S. (2004). Classroom assessment for student learning: doing it right--using it well. Assessment Training Institute.

Vogt, K. \& Tsagari, D. (2014) 'Assessment literacy of foreign language teachers: Findings of a European study'. Language Assessment Quarterly. 11(4), 374-402.

Volante, L., \& Fazio, X. (2007). Exploring Teacher Candidates' Assessment Literacy: Implications for Teacher Education Reform and Professional Development. Canadian Journal of Education, 30(3), 749-770.

Wiggins, G.P. (1994). Toward More Authentic Assessment of Language Performances. In C. R. Hancock (Ed.). Teaching, testing, and assessment: making the connection. Northeast Conference Report. Lincolnwood, IL: National Textbook Company.

Yamtim, V., \& Wongwanich, S. (2014). A study of state and approaches to improve classroom assessment literacy of primary school teachers. Procedia-Social and Behavioral Sciences, 116, 2998-3004.

Zhang, Z., \& Burry-Stock, J.A. ( 2003). Classroom assessment practices and teachers' self-perceived assessment skills. Applied Measurement in Education, 16(4), 323-342. 